\title{
WATER QUANTITY AND QUALITY MONITORING OF KOSYNTHOS RIVER, NORTH-EASTERN GREECE
}

\author{
V. PISINARAS \\ C. PETALAS \\ A. GEMITZI \\ V.A. TSIHRINTZIS*
}

Received: 17/01/07

Accepted: 02/04/07

\author{
Democritus University of Thrace \\ Department of Environmental Engineering \\ Laboratory of Ecological Engineering and Technology \\ 67100 Xanthi, Greece
}

*to whom all correspondence should be addressed: e-mail: tsihrin@otenet.gr

\begin{abstract}
An investigation of the quantitative and qualitative characteristics of Kosynthos river flow is presented. Four monitoring sites were established along Kosynthos river for the period October 2003 to October 2005 where discharge and water quality parameters were monitored. River flow processes have changed over the recent years due to canalization and diversion of flow, which have caused reduction in river losses from the study reach, thus affecting local aquifer recharge. Both anthropogenic activities and geological deposits were found to affect Kosynthos river hydrochemical regime. PCA proved to be a useful tool for the exploration of Kosynthos river dataset. Three PCs were rendered including a nutrient type component, a geochemical type component and a eutrophic type component. Continuing monitoring of this river is essential for two reasons: it recharges the aquifer used for water supply of the city of Xanthi, and discharges to Vistonis lagoon which is a very significant ecosystem.
\end{abstract}

KEYWORDS: river water quality, nutrients, principal component analysis.

\section{INTRODUCTION}

Anthropogenic impact on natural environments, and especially on aquatic ecosystems, is currently a topic of increasing concern. Deterioration of lake and river water quality is common in many aquatic systems. Potential causes are various point and non-point sources of pollution (Carpenter et al., 1998).

Human activities have affected the river systems in numerous ways, for example, through deforestation, urbanization, agricultural development, land drainage, pollutant discharge and flow regulation (dams, canalization, etc). River water quality may vary depending on morphological features, vegetation and activities in the river basin, as well as the location of monitoring sites, i.e., if there are installed upstream in the mountains or at the lower reaches of the river course (Brezonic et al., 1999).

Rainfall strongly controls water chemistry by determining the volume of water available to wash off, transport and dilute pollutants (Hem, 1985), governing the amount of river flow, and controlling flood events and subsequent flushing (Walling and Foster, 1975). The protection of groundwater from pollution is also considered very important; protecting surface waters interconnected with the aquifers from pollution also helps to maintain and improve groundwater quality.

In the frame of the present work, a monitoring investigation was performed to determine the pollution levels in Kosynthos river basin, Thrace, North-eastern Greece, and identify pollution sources, aiming at proposing management measures. The results of this study are presented herein. 


\section{MATERIALS AND METHODS}

\section{Study area description}

Kosynthos river is located in north-eastern Greece. Its total length is approximately $52 \mathrm{~km}$. It originates from Rhodope Mountains, and after traversing a basin of about $440 \mathrm{~km}^{2}$ that includes mountain terrain, agricultural plains and urban areas, it discharges to Vistonis lagoon (Figure 1). The major sources that can affect its water quality are agricultural, urban and industrial activities taking place in the lower reaches of the basin. The natural environment of the river is still relatively undisturbed in the greatest part of the basin. Water needs of the area are satisfied mainly by groundwater abstracted from numerous wells.

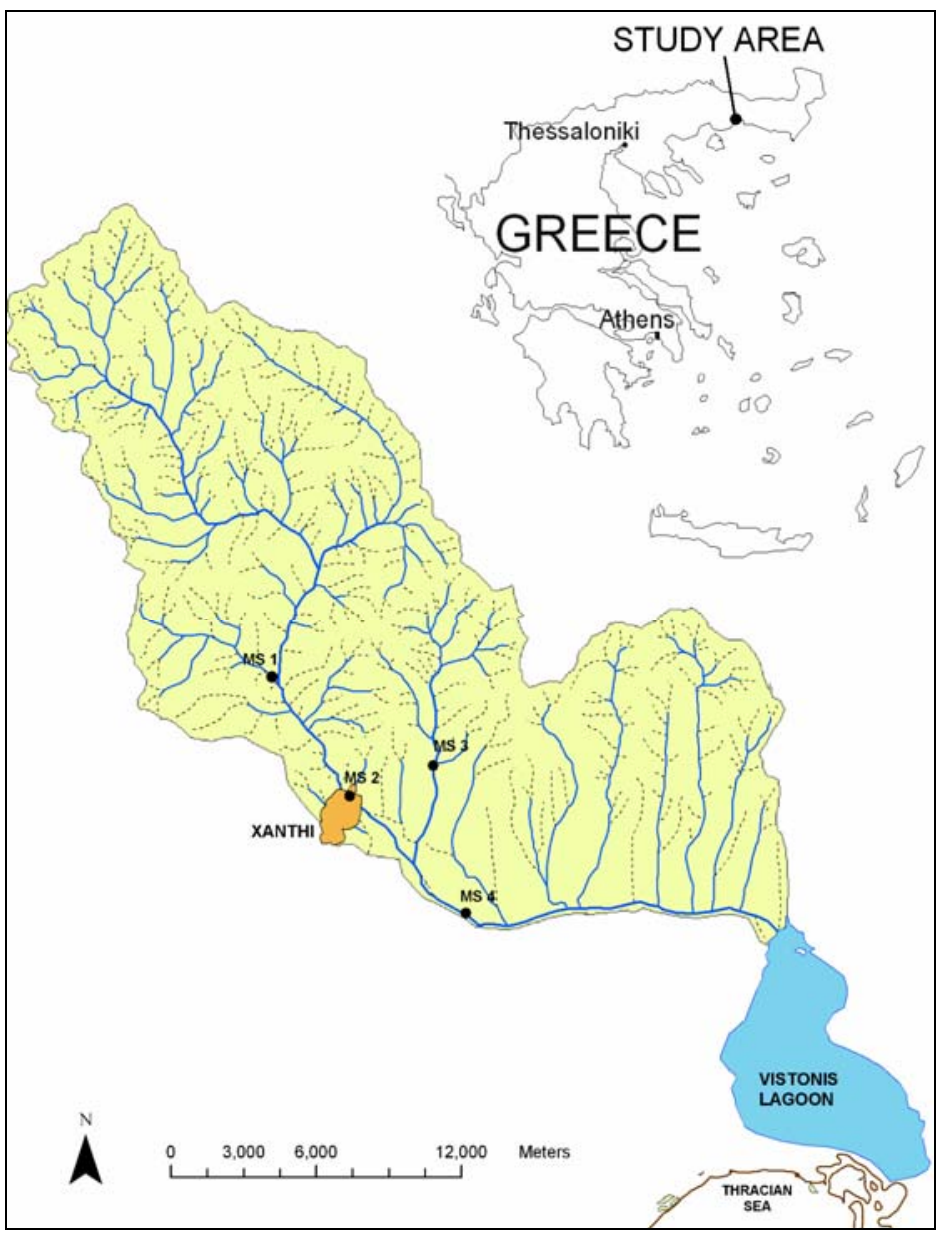

Figure 1. Map of the study area, including the monitoring sites (MS)

Geologically, Kosynthos catchment belongs entirely to Rhodope massif, consisting of old metamorphic rocks (gneisses, marbles, schsits), observed mainly at the northern part of the study area. Moreover, igneous rocks (granites, granodiorites) have intruded Rhodope massif, through magmatic events in tertiary times, and outcrop in the southern part of the area together with quaternary sediments. Precipitation averages $791 \mathrm{~mm}$ annually in the plain area, ranging from 368 to $1,307 \mathrm{~mm}$, while in the mountainous area it averages $1044 \mathrm{~mm}$ annually, ranging from 539 to $1,828 \mathrm{~mm}$.

Kosynthos river water quality is an important aspect, as water is used for irrigation purposes and also recharges the Xanthi's plain aquifer, which constitutes the potable and irrigation water supply of about 50,000 inhabitants. Moreover, Kosynthos river discharges into Vistonis lagoon, which is one of the most significant ecosystems of Greece, protected by the Ramsar Convention and belonging to EU NATURA 2000 sites. Over the past 20 years, the lagoon has suffered severe impacts due to point and non-point sources of pollution (Gikas et al., 2006a; 2006b). 
River flow and water quality monitoring was undertaken at four monitoring sites (MS) along Kosynthos river and its tributaries (Figure 1). Monitoring site 1 (MS 1) was located in tributary Gerakas, at the northern of the city of Xanthi. Monitoring site 2 (MS 2) was situated in the city of Xanthi. Monitoring site 3 (MS 3) was located in a significant tributary (Kimmeria Creek) of Kosynthos river near Kimmeria village, which confluences with Kosynthos upstream of monitoring site 4 (MS 4), located downstream of the city of Xanthi.

\section{River discharge measurements}

This study focuses on data collected between October 2003 and October 2005. Fourty eight discharge measurements were conducted using a Valeport model 801 flowmeter. From October 2003 to October 2004 discharge was measured once every two weeks, while from November 2004 to November 2005 discharge measurements were conducted weekly. Peak flows were not measured due to access limitations.

\section{Sample collection and analytical methods}

Field $\mathrm{pH}$, electrical conductivity (EC), dissolved oxygen (DO) and temperature (T) were measured simultaneously with discharge measurements using appropriate equipment (WTW). Sampling and analyses were based on standard methods for surface waters (APHA, 1998). One sample also was collected from each monitoring site once or twice a month, from October 2003 to June 2004, to determine heavy metal (Cu, Fe, Zn, Mn, Pb, Cr, Ni and Cd) concentrations. Furthermore, eight sets of samples were collected from December 2004 to October 2005 to determine $\mathrm{NO}_{3}^{-}, \mathrm{NO}_{2}^{-}, \mathrm{NH}_{4}{ }^{+}, \mathrm{PO}_{4}{ }^{3-}, \mathrm{SO}_{4}{ }^{2-}$ and $\mathrm{HCO}_{3}{ }^{-}$.

\section{Principal component analysis}

PCA and factor analysis in general, are useful tools and have been widely used for water quality exploration. PCA seeks to establish combinations of variables capable of describing the principal tendencies observed while studying a given matrix (Bengraine and Marhaba, 2003; Farnham et al., 2003).

PCA technique extracts the eigenvalues and eigenvectors from the covariance matrix of original variables. It allows finding associations between variables, thus, reducing the dimensionality of the dataset. The principal components (PCs) are the uncorrelated (orthogonal) variables, obtained by multiplying the original correlated variables with the eigenvector (loadings or weightings). The eigenvalues of the PCs are the measure of their associated variance. The participation of the original variables in the PCs is given by the loadings, and the individual transformed observations are called scores (Hoffman and Lieberman, 2000; Reed et al., 1998; Sabater et al., 1990). The Bartlett's sphericity test was applied to the correlation matrix of variables for assessing the adequacy of PCA (Sabater et al., 1990). Following the criteria of Cattell and Jaspers (Huntley et al., 1995), PCs with eigenvalue $>1$ were retained. Also, a varimax rotation was performed to address the problem of variables loading moderately (or equally) on one or more of the axes. A secure increased PCs chemical/environmental significance is the consequence of this rotation on the interpretation of the results.

Here, $\mathrm{PCA}$ was performed for $\mathrm{pH}, \mathrm{EC}, \mathrm{DO}, \mathrm{NO}_{3}{ }^{-}, \mathrm{NO}_{2}{ }^{-}, \mathrm{NH}_{4}{ }^{+}, \mathrm{PO}_{4}{ }^{3-}, \mathrm{SO}_{4}{ }^{2-}$ and $\mathrm{HCO}_{3}{ }^{-}$in all the monitoring sites combined, with a view to assess the compositional differences among different water samples and the influence of anthropogenic activities for the whole basin.

\section{RESULTS AND DISCUSSION \\ Water discharge}

The temporal variation of water discharge across Kosynthos river is shown in Figure 2. Surface water discharge in MS 1 ranged from 0.0065 to $0.4 \mathrm{~m}^{3} \mathrm{~s}^{-1}$, while in MS 2 ranged from 0.165 to $7.33 \mathrm{~m}^{3} \mathrm{~s}^{-1}$. In MS 3, discharge varied from 0 to $1.15 \mathrm{~m}^{3} \mathrm{~s}^{-1}$, while in MS 4 from 0.129 to $8.32 \mathrm{~m}^{3} \mathrm{~s}^{-1}$. Kosynthos river has a flushy hydraulic regime, because of its small size and steep gradient. River flow becomes decreasingly flushy downstream of MS 2 as gradient becomes milder. The quantity of water which infiltrates and recharges the underlying aquifer of Xanthi's plain does not show a continuous and clear trend and ranges from 0 to $0.824 \mathrm{~m}^{3} \mathrm{~s}^{-1}$. This could be attributed to the human activities that have affected the river system in 
numerous ways and especially to flow regulation through diversion and canalization. Specifically, the main course of Kosynthos river used to follow a direction south of MS 4 and discharge directly to Thracian sea (Figure 1). The river course, downstream of MS 4 was canalized and diverted to a west-south direction in 1958. In this way, many kilometers of river course were abandoned, thus affecting adversely the groundwater recharge of the underlying aquifer system. In a similar way, the numerous small torrents in the area lost long reaches of their courses with the same adverse result.

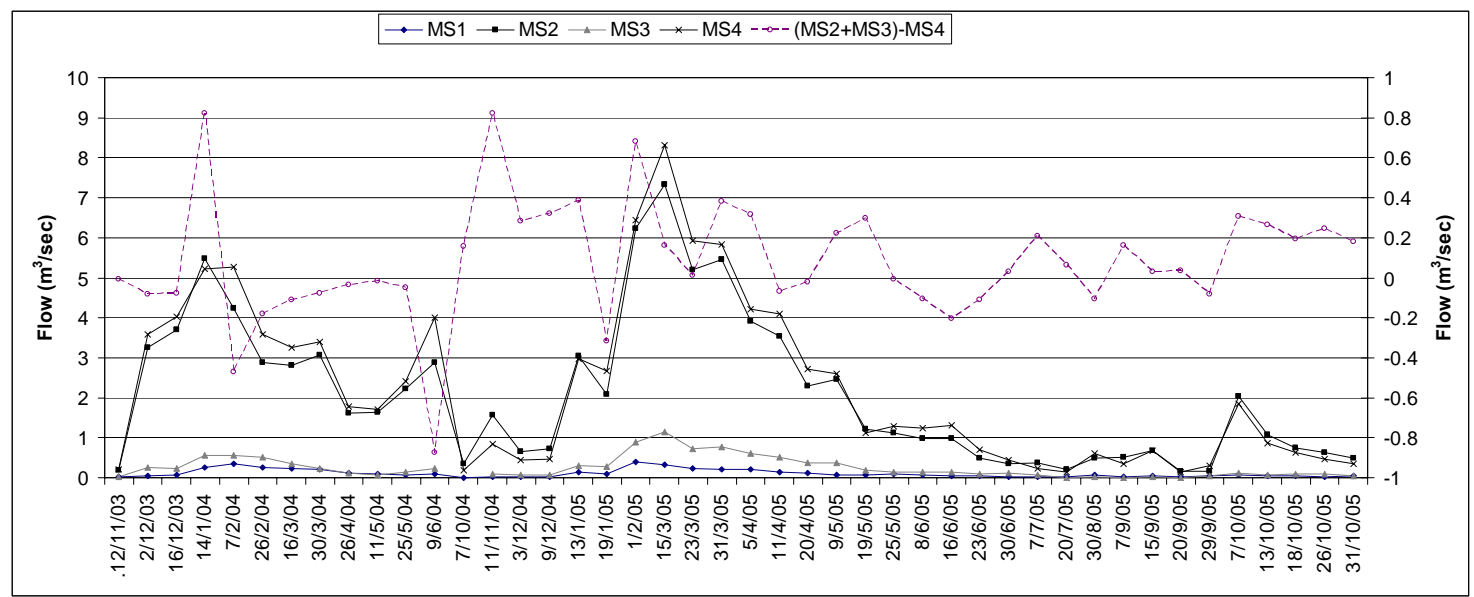

Figure 2. Water discharge at the four monitoring sites in Kosynthos river. The right axis corresponds to flow difference between MS2 and MS3 minus MS4, indicating, when positive,

pH groundwater recharge

A statistical overview of the water quality parameters for each site is given in Table 1, while their temporal distribution is shown in Figure 3. In general, the examined surface waters were in the alkaline $\mathrm{pH}$ range without remarkable variations, but with a trend to increase during spring and summer in all monitoring sites. In summer, $\mathrm{pH}$ values were more than 8.5 , thus exceeding the WHO limits (WHO, 1984) for drinking water. The highest $\mathrm{pH}$ values were observed in MS 3, while the lowest in MS 2. $\mathrm{pH}$ variations and DO levels, in turn, regulate most of the biochemical and chemical reactions affecting water composition. Thus, an increase in the phytoplankton population (from March to July) produces an increase in the $\mathrm{pH}$ value and oxygen supersaturation, due to high photosynthetic activity (Fourqurean et al., 1993).

\section{Conductivity}

Conductivity measurement provides an indication of ion concentration. The same trend with $\mathrm{pH}$ was observed for EC. Mean and range of EC in each monitoring site are presented in Table 1. The highest conductivity was observed in MS $3\left(473 \mu \mathrm{S} \mathrm{cm}^{-1}\right.$, Nov. 2004) while the lowest was observed in MS 2 (118 $\mu \mathrm{sm}^{-1}$, Sep. 2004) with the highest range observed in MS 4. Human activities, as well as the nature of geological deposits through which the river flows, are the two main reasons for the higher values observed at monitoring sites 1, 3 and 4, respectively. More specifically, the dilution processes of the marbles and limestones existing in the north of the study area increases the ionic content of river water, thus leading to higher conductivity values in MS1 and MS3. High values were expected during the warm period, due to low water flow and high temperatures.

\section{DO}

Mean and range of DO at each monitoring site are shown in Table 1. DO is the single and the most important component of surface water that initiates self-purification processes, thus contributing to the maintenance of aquatic organisms. This parameter is most reactive and reliable in the short-term than most chemical constituents in water. DO concentration varied from 3.8 (MS 1, Sep. 2005) to $15 \mathrm{mg} \mathrm{l}^{-1}$ (MS 3, Dec. 2004). DO in the examined waters showed large variations. Variations were rather temporal than spatial. Lower values were expected during the warm period, due to higher water temperatures. 
Table 1. Mean and range values of various river water parameters

\begin{tabular}{|c|c|c|c|c|c|c|c|c|}
\hline & \multicolumn{2}{|c|}{ MS 1} & \multicolumn{2}{|c|}{ MS 2} & \multicolumn{2}{|c|}{ MS 3} & \multicolumn{2}{|r|}{ MS 4} \\
\hline & Mean & Range & Mean & Range & Mean & Range & Mean & Range \\
\hline $\mathrm{pH}$ & 7.99 & $5.56-9.08$ & 8.11 & $4.79-9.01$ & 8.41 & $7.78-9.29$ & 8.06 & $6.01-9.2$ \\
\hline $\begin{array}{c}\text { EC } \\
\left(\mu \mathrm{Scm}^{-1}\right)\end{array}$ & 342.20 & $208-439$ & 203.98 & $118-285$ & 362.12 & $226-473$ & 291.36 & $139-478$ \\
\hline $\begin{array}{c}\text { DO } \\
\left(\mathrm{mg} \mathrm{l}^{-1}\right)\end{array}$ & 7.52 & $3.82-11.71$ & 7.96 & $4.64-12.6$ & 7.79 & $4.4-15$ & 8.60 & $4.36-12.38$ \\
\hline $\begin{array}{c}\mathbf{T} \\
\left({ }^{\circ} \mathrm{C}\right) \\
\end{array}$ & 14.43 & $5.1-26.2$ & 14.17 & $4.8-29$ & 16.50 & $7.2-28.1$ & 16.30 & $5.9-31.1$ \\
\hline $\begin{array}{c}\mathrm{NO}_{2}^{-} \\
\left(\mu \mathrm{g}-\mathrm{N}^{-1}\right)\end{array}$ & 0.26 & $0-1.38$ & 1.68 & $0-6.21$ & 1.94 & $0-12.8$ & 6.72 & $0.3-32.4$ \\
\hline $\begin{array}{c}\mathrm{NO}_{3}^{-} \\
\left(\mu \mathrm{g}-\mathrm{N}^{-1}\right)\end{array}$ & 348.58 & $65.6-929.8$ & 329.16 & $45.4-731.9$ & 457.07 & $68-1153$ & 501.21 & $64.7-1041.8$ \\
\hline $\begin{array}{c}\mathbf{N H}_{4}^{+} \\
\left(\mu \mathrm{g}-\mathrm{NI}^{-1}\right)\end{array}$ & 1.05 & $0.24-2.25$ & 0.77 & $0.25-2.92$ & 0.64 & $0.3-1.4$ & 1.55 & $0.4-7.3$ \\
\hline $\begin{array}{l}\mathbf{P O}_{4}{ }^{3-} \\
\left(\mu \mathrm{I}^{-1}\right)\end{array}$ & 120.57 & $22.7-268.2$ & 84.20 & $14.6-162.7$ & 47.95 & $12.7-164.6$ & 78.75 & $26.4-134.6$ \\
\hline $\begin{array}{l}\mathrm{SO}_{4}{ }^{2-} \\
\left(\mu \mathrm{I} \mathrm{I}^{-1}\right)\end{array}$ & 27.90 & $20.21-35.4$ & 25.70 & $16-38.5$ & 35.22 & $20.3-47$ & 31.76 & $22.2-47.6$ \\
\hline $\begin{array}{l}\mathrm{HCO}_{3}^{-} \\
\left(\mu \mathrm{gl}^{-1}\right)\end{array}$ & 180.54 & $131-225$ & 89 & $58-156$ & 166 & $115-225$ & 103 & $70-137$ \\
\hline $\begin{array}{c}\mathrm{Cu} \\
\left(\mu \mathrm{gl}^{-1}\right)\end{array}$ & 6.56 & $3.5-10.8$ & 6.54 & $3.5-12$ & 27.22 & $14.5-52.8$ & 7.23 & $3.8-10.8$ \\
\hline $\begin{array}{c}\mathbf{F e} \\
\left(\mu \mathrm{g} \mathrm{I}^{-1}\right)\end{array}$ & 91.94 & $11.5-221.5$ & 101.33 & $13.8-218$ & 171.69 & $19.5-482$ & 122.21 & $28.3-203.5$ \\
\hline $\begin{array}{c}\mathbf{Z n} \\
\left(\mu \mathrm{gl}^{-1}\right)\end{array}$ & 176.48 & $47.5-637.5$ & 183.33 & $72.9-514$ & 203.32 & $74.6-438$ & 141.01 & $57.2-327.1$ \\
\hline $\begin{array}{c}\text { Mn } \\
\left(\mu \mathrm{gl}^{-1}\right)\end{array}$ & 43.65 & $7-173.8$ & 25.10 & $0-106$ & 45.66 & $10.5-154$ & 58.54 & $12-127.3$ \\
\hline $\begin{array}{c}\mathbf{P b} \\
\left(\mu \mathrm{gl}^{-1}\right)\end{array}$ & 0.21 & $0-2.5$ & 0.63 & $0-5$ & 0.94 & $0-5$ & 0.42 & $0-5$ \\
\hline $\begin{array}{c}\mathbf{C r} \\
\left(\mu \mathrm{gl}^{-1}\right)\end{array}$ & 0.31 & $0-2$ & 8.10 & $0-24.2$ & 3.13 & $0-16.5$ & 2.85 & $0-11.8$ \\
\hline $\begin{array}{c}\mathbf{N i} \\
\left(\mu \mathrm{gl}^{-1}\right)\end{array}$ & 0.46 & $0-5$ & 1.04 & $0-9.8$ & 0.91 & $0-7.3$ & 0.83 & $0-5.3$ \\
\hline $\begin{array}{c}\mathbf{C d} \\
\left(\mu \mathrm{gl}^{-1}\right)\end{array}$ & 2.85 & $1.75-4.25$ & 2.96 & $1.5-3.8$ & 3.13 & $2.3-4$ & 3.40 & $2.2-5.3$ \\
\hline
\end{tabular}

\section{Temperature}

Mean and range of water temperature at each monitoring site are given in Table 1 . Water temperature showed high seasonal variations and ranged from $4.89^{\circ} \mathrm{C}$ during winter (December 2005) to $31.1^{\circ} \mathrm{C}$ during early summer (July 2005). Although MS 1 is located in higher elevation, the lowest temperature values were observed in MS 2. This indicates that Gerakas tributary (MS1) is warmer than the main river because of the smaller discharge. The highest temperature values were observed just after the city of Xanthi (MS 4). As expected, high water temperatures were observed during the warm period from May to September. Thermal increase can also be caused by the absence of trees and vegetation that shade and cool streams. This is more obvious in MS 4 where the riparian vegetation is completely absent. High temperature, during the warm period, can result in intensive evaporation and flow minimization, which may lead to the accumulation of organic matter, responsible for oxygen depletion in the water (Justic et al., 1997). 


\section{Speciation of nitrogen}

Table 1 presents mean and range of nutrient concentrations at each monitoring site, while the temporal distributions are shown in Figure 4. Nearly in all monitoring sites, the dominant soluble nitrogen form was $\mathrm{NO}_{3}{ }^{-}$followed by $\mathrm{NH}_{4}{ }^{+}$and $\mathrm{NO}_{2}{ }^{-}$. Mean values of nitrates at all monitoring sites were higher than the value of $100 \mathrm{~g} \mathrm{I}^{-1}$ reported by Meybeck $(1982 ; 1998)$ as mean nitrate concentration found in unpolluted rivers. Nevertheless, all mean concentrations were lower than the maximum permissible concentration for drinking water, and thus they could be classified as non-polluted surface freshwaters according to the "Nitrate Directive" (Jarvie et al., 1998). The highest mean nitrate concentration was observed in MS 3, indicating nitrate inputs from urban and agricultural runoff, as higher values were observed after flood events. Nitrate concentration maxima were observed at the end of winter and during spring, and minima during the summer (Vega et al., 1998). The peak concentration was partially a result of rainfall, washing out nitrates from fertilizers and urban activities (van der Molen et al., 1998). A similar pattern was also observed for ammonium and phosphates.

Mean nitrite values at the various monitoring sites ranged from 0 up to $32 \mu \mathrm{gl}^{-1}$. The highest mean and monthly $\mathrm{NO}_{2}{ }^{-}$concentration was observed in MS 4 due to higher nitrogen inputs from urban runoff. According to Meybeck (1982), the mean concentration for unpolluted water is $1.5 \mu \mathrm{g} \mathrm{l^{-1 }}$.

Mean values of ammonium ranged between $0.2 \mu \mathrm{g} \mathrm{I}^{-1}$ and $7.3 \mu \mathrm{g} \mathrm{I}^{-1}$. The maximum permissible concentration for drinking water is $390 \mathrm{\mu g} \mathrm{I}^{-1}$, whereas the mean value reported for the unpolluted water is $15 \mathrm{\mu g} \mathrm{I}^{-1}$ (Meybeck, 1982). Higher levels were found in MS 4 and could be related to anthropogenic activities, following a similar to nitrate pattern.
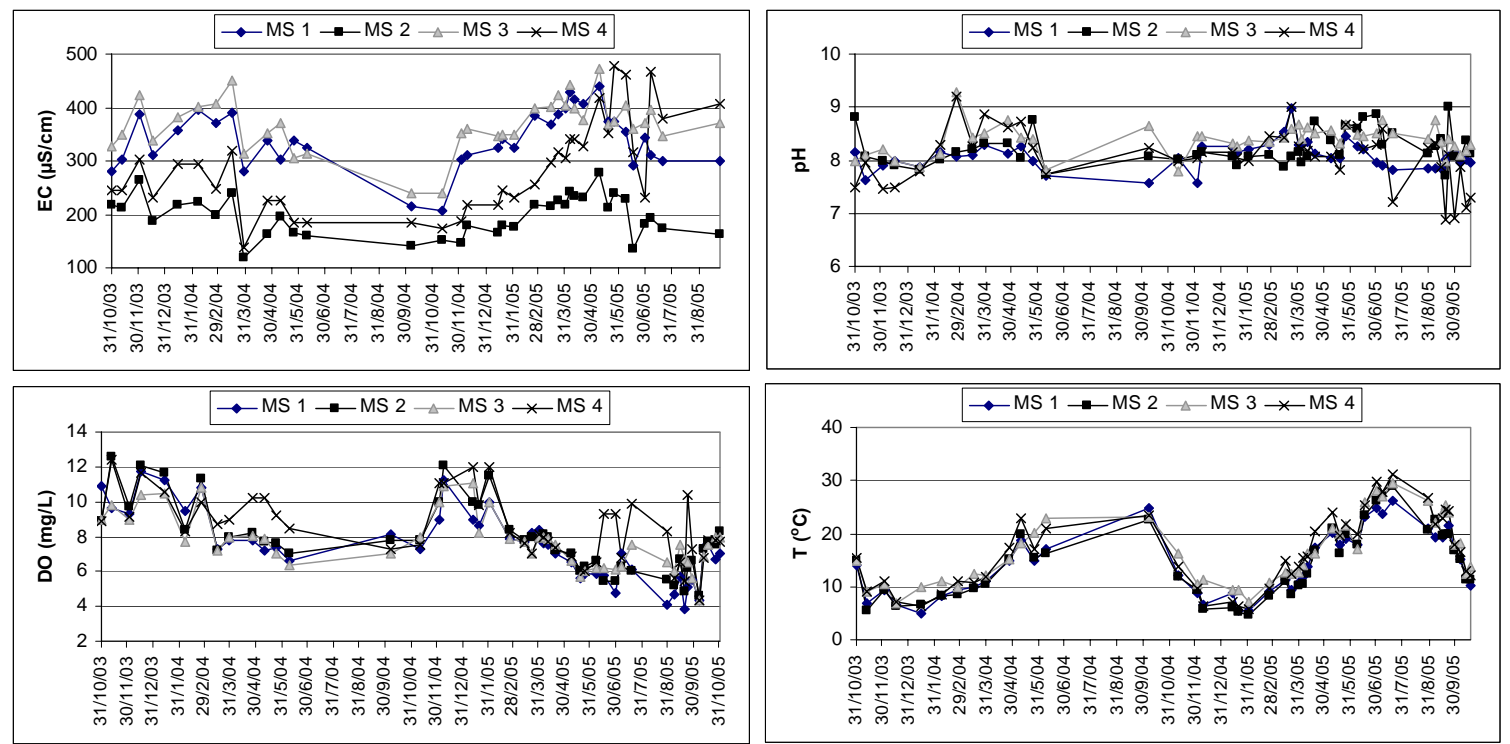

Figure 3. $\mathrm{EC}, \mathrm{pH}, \mathrm{DO}$ and $\mathrm{T}$ temporal vatiation at the four monitoring sites in Kosynthos river

\section{Ortho-phosphates}

Mean and ranges of $\mathrm{PO}_{4}{ }^{3-}$ concentration determined in this study are presented in Table 1. Mean values of $\mathrm{P}_{-} \mathrm{PO}_{4}{ }^{3-}$ at most monitoring sites in different sampling times, exceeded the UK criterion $\left(0.1 \mathrm{mg} \mathrm{l}^{-1}\right)$ for running freshwaters subject to eutrophication (Young et al., 1999). Ortho-phosphate is one of the essential plant nutrients, which in low concentrations, controls the primary productivity in the aquatic environment (Diaz et al., 2001). An understanding of its sources and transport in catchments is necessary to help identify and reduce eutrophication risks (Cooper et al., 2002). The transport of phosphorus from a wide range of sources affects the overall quality of river systems.

\section{Sulfates and bicarbonates}

Sulfates showed remarkable seasonal variation at the majority of the monitoring sites with higher concentrations being recorded during summer and autumn. The highest mean values 
were observed at monitoring sites 3 and 4 which follow a similar trend. Higher sulphate concentrations can be attributed to geochemical influence. Bicarbonates constitute the major ion for Kosynthos river water in all monitoring sites. The highest mean values were measured in monitoring sites 2 and 4 . They originate from the dilution of limestones and marbles of the mountainous part of Kosynthos river basin.
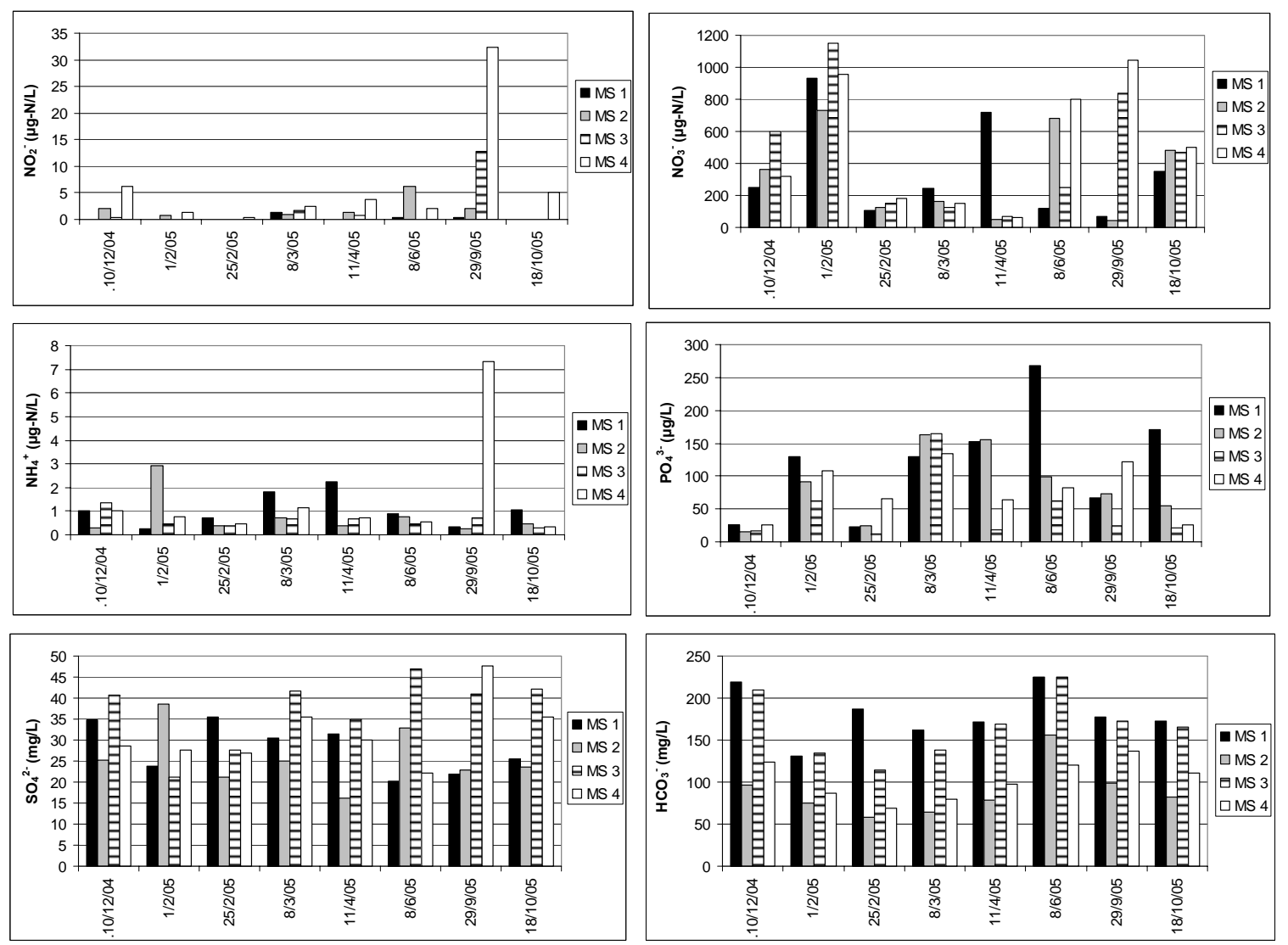

Figure 4. $\mathrm{NO}_{2}{ }^{-}, \mathrm{NO}_{3}{ }^{-}, \mathrm{NH}_{4}{ }^{+}, \mathrm{PO}_{4}{ }^{3-}, \mathrm{SO}_{4}{ }^{2-}$ and $\mathrm{HCO}_{3}{ }^{-}$concentrations at the four monitoring sites in Kosynthos river

\section{Heavy metals}

The mean concentrations of some examined heavy metals, and especially of $\mathrm{Cu}, \mathrm{Fe}, \mathrm{Zn}$ and $\mathrm{Pb}$, show significant variation between MS 3 and the other monitoring sites (Table 1, Figure 5). Higher $\mathrm{Mn}$ and $\mathrm{Cr}$ concentrations were observed in MS 4 and MS 2, respectively. The mean concentrations of $\mathrm{Ni}, \mathrm{Cd}$ and $\mathrm{Pb}$ showed little variations between different monitoring sites (Table 1), suggesting influence from the geological deposits rather than from point sources. The highest concentrations for $\mathrm{Cu}, \mathrm{Fe}, \mathrm{Zn}, \mathrm{Mn}, \mathrm{Pb}, \mathrm{Cr}$, Ni and $\mathrm{Cd}$ were 52.8, 482.0, 637.5, 173.5, 5.0, 24.5, 9.8 and $5.8 \mu \mathrm{g} \mathrm{I}^{-1}$, respectively, with $\mathrm{Fe}, \mathrm{Mn}, \mathrm{Cr}$ and Cd concentrations exceeding the WHO limits (WHO, 1984) for drinking water. These values were usually observed after flood events. A significant part of these metals probably originates in heavymetal rich geologic formations that exist in Kosynthos river catchment. The existence of mining facilities in the sub-basin of Kimmeria tributary (MS 3) demonstrates this fact.

\section{Principal component analysis}

The Bartlett's sphericity test carried out on the correlation matrix of variables, shows that significance is equal to zero, thus indicating that PCA can achieve a significant reduction of the dimensionality of the original dataset. PCA was performed on normalized data using the Factor procedure in the SPSS software package (SPSS, 2002). The loadings of the measured variables on the several PCs are shown in Table 2. PCA rendered three significant PCs (eigenvalue $>1$ ) explaining $68.01 \%$ of the total variance of the dataset. PC1 explains $26.43 \%$ of the variance and is contributed mainly by $\mathrm{NO}_{2}{ }^{-}, \mathrm{NO}_{3}{ }^{-}$and $\mathrm{NH}_{4}{ }^{+}$. This nutrient-type component may be interpreted as representing influences from agricultural and urban runoff, 
and atmospheric deposition, which are considered as nonpoint sources. PC2 accounting for $25.60 \%$ of the variance in the whole dataset, was correlated with $\mathrm{EC}, \mathrm{SO}_{4}{ }^{2-}$ and $\mathrm{HCO}_{3}{ }^{-}$, thus suggesting a geochemical source of variability. Finally, PC3 which explains $15.98 \%$ of the total variance is positively correlated with $\mathrm{DO}$ and negatively correlated with $\mathrm{PO}_{4}{ }^{3-}$. $\mathrm{As} \mathrm{PO}_{4}{ }^{3-}$ concentration increases, eutrophic conditions are maintained thus leading to DO depletion. Therefore, PC3 may be considered as a eutrophic type component.
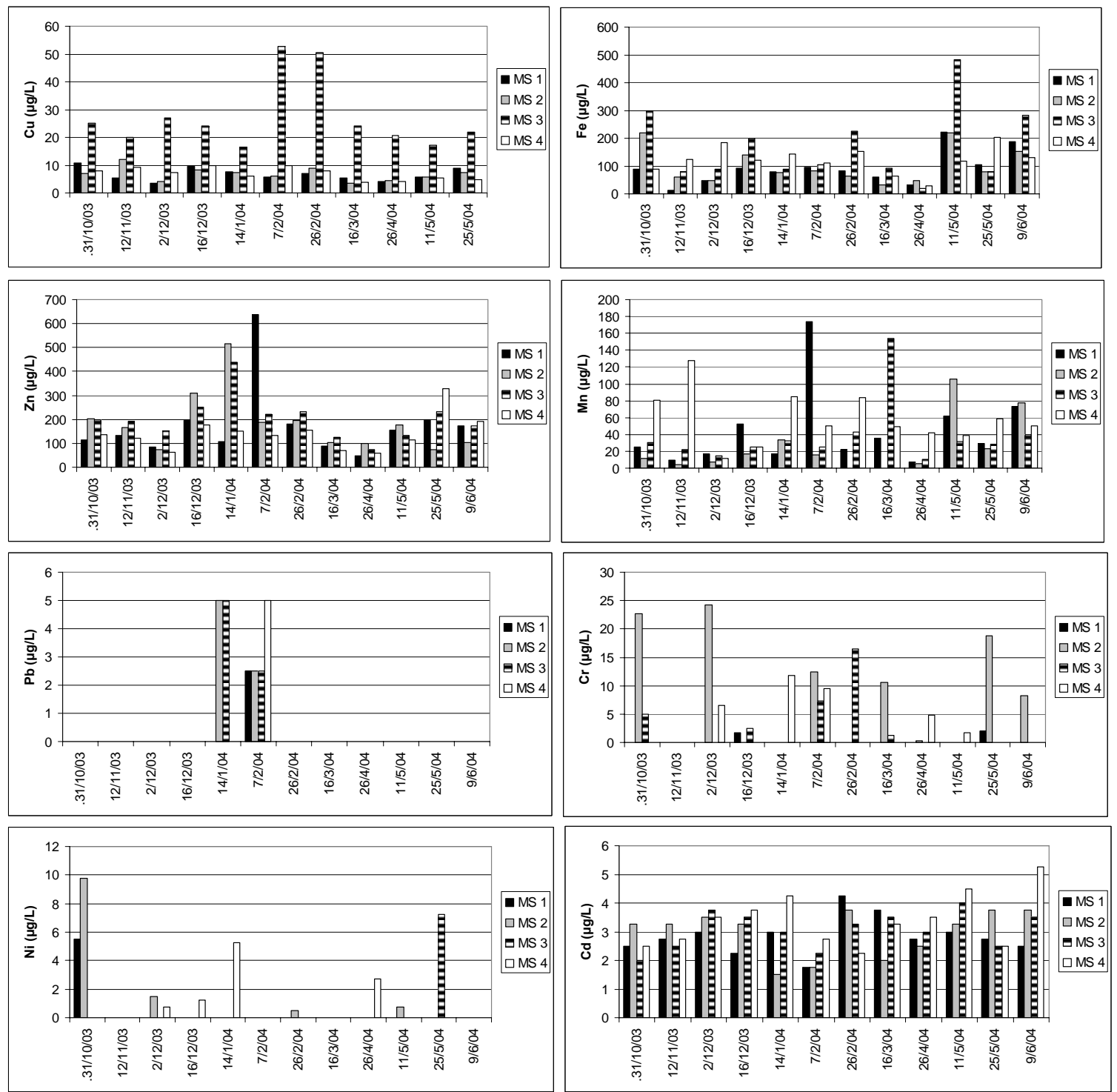

Figure 5. Heavy metals temporal vatiation at the four monitoring sites in Kosynthos river

Table 2. Loadings of the measured variables on the seven significant PCs

\begin{tabular}{|c|c|c|c|}
\hline Parameter & PC1 & PC2 & PC3 \\
\hline $\mathbf{E C}$ & 0.26 & 0.87 & -0.23 \\
\hline $\mathbf{p H}$ & -0.40 & 0.35 & 0.07 \\
\hline $\mathbf{D O}$ & 0.13 & -0.40 & 0.71 \\
\hline $\mathbf{N O}_{\mathbf{2}}{ }^{-}$ & 0.85 & 0.20 & -0.11 \\
\hline $\mathbf{N O}_{3}{ }^{-}$ & 0.64 & -0.01 & 0.28 \\
\hline $\mathbf{N H}_{4}{ }^{-}$ & 0.90 & 0.15 & -0.13 \\
\hline $\mathbf{P O}_{4}{ }^{3-}$ & 0.13 & -0.14 & -0.82 \\
\hline $\mathbf{S O}_{4}{ }^{2-}$ & 0.41 & 0.68 & 0.31 \\
\hline $\mathbf{H C O}_{3}{ }^{-}$ & -0.07 & 0.85 & -0.08 \\
\hline
\end{tabular}




\section{CONCLUSIONS}

A considerable dataset concerning river discharge, physicochemical parameters, nutrient speciation and heavy metals has been gathered for the surface waters of Kosynthos river basin located at North-eastern Greece.

River flow processes have changed over the last years due to canalization and diversion of flow affecting the local aquifer recharge, which does not show a clear and continuous trend. The nitrate and nitrite concentrations were found below the levels established for potable water $\left(50 \mathrm{mg} \mathrm{I}^{-1} \mathrm{NO}_{3}{ }^{-}\right)$. Phosphate concentrations sometimes exceeded eutrophication trigger levels. Phosphate concentrations were significantly higher during winter and spring due to rainfall and snow melting. From the four monitoring sites, the most polluted is the most downstream mainly because of urban and agricultural runoff. There is a clear tendency for $\mathrm{pH}$ and EC to increase from spring to summer and to decrease during autumn and winter, especially after flood events. T and DO variation follows a seasonal trend. Significant heavy metal concentrations, sometimes exceeding the WHO limits for drinking water, were observed especially in MS 3, which can be attributed to geological influence.

PCA proved to be a useful tool for the exploration of Kosynthos river dataset. PCA rendered three significant PCs from which the first one is a nutrient type component, the second one is a geochemical influence type component and the last one is a eutrophic type component.

Monitoring of this river is essential for two reasons: it recharges the aquifer used for water supply of the city of Xanthi, and discharges in Vistonis lagoon which is a very valuable ecosystem.

\section{REFERENCES}

APHA, (1998) Standard Methods for the Examination of Water and Wastewater, $20^{\text {th }}$ Edition.

Bengraine K. and Marhaba T.F., (2003), Using principal component analysis to monitor spatial and temporal changes in water quality, Journal of Hazardous Materials, B100, 179-195.

Brezonic P., Hatch K., Mulla L. and Perry D., (1999), Management of diffuse pollution in agricultural watersheds: lessons from the Minnesota river basin, Water Science and Technology, 39, 323-330.

Carpenter S.R., Caraco N.F., Correll D.L., Howarth R.W., Shawley A.N. and Smith V.H., (1998), Nonpoint pollution of surface waters with phosphorus and nitrogen, Ecological Applications, 8(3), 559-568.

Cooper D.M., House W.A., Reynolds B., Hughes S., May L. and Gannon B., (2002), The phosphorus budget of the Thames catchment, Oxfordshire, UK: 2 Modelling, Science of the Total Environment, 282/283, 435-457.

Diaz F., Raimbault P., Boudjellal B., Garcia N. and Moutin T., (2001), Early spring phosphorus limitation of primary productivity in a NW Mediterranean coastal zone (Gulf of Lions), Marine Ecology Progress Series, 211, 51-62.

Gikas G.D., Yiannakopoulou T. and Tsihrintzis V.A., (2006a), Modeling of non-point source pollution in a Mediterranean drainage basin, Environmental Modeling and Assessment, 11, 219-234.

Gikas G.D., Yiannakopoulou T. and Tsihrintzis V.A., (2006b) Water quality trends in a coastal lagoon impacted by non-point source pollution after protective measures Hydrobiologia, 563(1), 385-406.

Farnham I.M., Johannesson K.H., Singh A.K., Hodged V.F. and Stetzenbach K.J., (2003), Factor analytical approaches for evaluating groundwater trace element chemistry data, Analytica Chimica Acta, 490, 123-138.

Fourqurean J.W., Jones R.D. and Zieman J.C., (1993), Processes influencing water column nutrient characteristics and phosphorus limitation of phytoplankton biomass in Florida Bay, FL, USA: inferences from spatial distributions, Estuarine, Coastal and Shelf Science, 36(3), 295314.

Hem J.D., (1985), Study and interpretation of the chemical characteristics of natural water (3d ed.), U.S. Geological Survey, Water-Supply Paper 2254.

Hoffman J.L. and Lieberman S.E., (2000), Report OFR 00-1, New Jersey Department of Environmental Protection. 
Huntley S.L., Bonnevie N.L. and Wenning R.J. (1995), Polycyclic aromatic hydrocarbon and petroleum hydrocarbon contamination in sediment from the Newark Bay Estuary, New Jersey, Archives of Environmental Contaminant Toxicology, 28, 93-107.

Jarvie H.P., Whitton B.A. and Neal C., (1998), Nitrogen and phosphorus in east coast British rivers: speciation, sources and biological significance, Science of the Total Environment, 210/211, 79-109.

Justic D., Rabalais N.N. and Turner R.E., (1997), Impacts of climate change on net productivity of coastal waters: implications of carbon budgets and hypoxia, Climate Research, 8, 225-237.

Meybeck M. (1982) Carbon, nitrogen, and phosphorus transport by world rivers, American Journal of Science, 282, 401-450.

Meybeck M., (1998,) Man and river interface: multiple impacts on water and particulates chemistry illustrated in the Seine river basin, Hydrobiologia, 373, 1-17.

Reed T.S., Centinaro G.L., De-Luca M.J. and Oden J.H., (1998), USGS Report NJ-971.

Sabater F., Sabater S. and Armengol J. (1990), Chemical characteristics of a Mediterranean river as influenced by land use in the watershed, Water Research, 24(2), 143-155.

SPSS Base 11.0 for Windows (2002), SPSS Inc.

Vega M., Pardo R., Barrado E. and Deban L., (1998), Assessment of seasonal and polluting effects on the quality of river water by exploratory data analysis, Water Research, 32(12), 3581-3592.

Van-der-Molen D.T.A., Breeuwsma X. and Boers P.C., (1998), Agricultural nutrient losses to surface water in the Netherlands: impacts, strategies and perspectives, Journal of Environmental Quality, 27, 4-11.

Walling D.E. and Foster I.D.L., (1975), Variations in the natural chemical concentration of river water during flood flows and the lag effect: some further comments, Journal of Hydrology, 26, 237-244.

W.H.O. (1984) Guidelines for drinking-water quality. Vol. 2, Health criteria and other supporting information, Geneva.

Young R.A., Morse G.K., Scrimshaw M.D., Kinniburgh J.H., Mac-Leod C.L. and Lester J.N., (1999), The relation between phosphorus and eutrophication in the Thames catchment, UK, Science of the Total Environment, 228, 157-183. 